\title{
Eating habits, lifestyle behaviors and stress during the COVID-19 pandemic quarantine among Peruvian adults
}

\author{
Hellen S Agurto ${ }^{1}$, Ana L Alcantara-Diaz ${ }^{1,2}$, Eduardo Espinet-Coll ${ }^{3}$, Carlos J Toro-Huamanchumo ${ }^{\text {Corresp. } 4}$ \\ 1 Unidad de Investigación Multidisciplinaria, Clínica Avendaño, Lima, Peru \\ 2 SCIEMVE, Sociedad Científica Veritas, Chiclayo, Peru \\ 3 Gastrodex, Hospital Universitario Quiron Dexeus, Barcelona, Spain \\ ${ }^{4}$ Unidad de Investigación para la Generación y Síntesis de Evidencias en Salud, Universidad San Ignacio de Loyola, Lima, Peru \\ Corresponding Author: Carlos J Toro-Huamanchumo \\ Email address: toro2993@hotmail.com
}

Background and aims: The coronavirus disease 2019 (COVID-19) outbreak has led to an unprecedented public health crisis. In Peru, although the quarantine is no longer mandatory, it was during the first months of 2020. To date, no studies have assessed the impact of the COVID-19 on the eating patterns and lifestyle context in the country. We aimed to describe the eating habits, lifestyle behaviors and stress during the COVID-19 pandemic quarantine among Peruvian adults.

Methods: We conducted a cross-sectional study. We used an online survey to collect information regarding eating habits, self-perceived stress and sedentary lifestyle among adults over 18 years of age residing in Lima-Peru and who complied with strict home quarantine. We presented our data according to the weight variation of the participants.

Results: A total of 686 were finally included in the study. The $82.9 \%$ were female, the median BMI was $25.97 \mathrm{~kg} / \mathrm{m} 2$ (IQR: $23.37-29.41$ ) and $68.2 \%$ reported a significant variation in their weight (38.8\% increased and 29.3 lost weight). All bad habits were significantly associated with weight gain, except for prolonged fasting. Additionally, a sitting time longer than usual $(p=0.001)$, being in front of a screen for more than five hours in the last week $(p=0.002)$, and most of the stressful scenarios were significantly associated with weight gain.

Conclusion: Almost four out of ten participants gained weight during the quarantine. This was associated with unhealthy eating habits, physical inactivity, and stressful scenarios. 
1 Eating habits, lifestyle behaviors and stress during the COVID-19 pandemic quarantine

2 among Peruvian adults

3

4 Authors

5 Hellen S. Agurto (1)

6 Ana L. Alcantara-Diaz $(1,2)$

7 Eduardo Espinet-Coll (3)

8 Carlos J. Toro-Huamanchumo $(1,4)$

9

10 Affiliation

$11{ }^{1}$ Clínica Avendaño, Unidad de Investigación Multidisciplinaria, Lima, Peru

122 SCIEMVE, Sociedad Científica Veritas, Chiclayo, Peru

$13{ }^{3}$ Gastrodex, Hospital Universitario Quiron Dexeus, Spain

144 Universidad San Ignacio de Loyola, Unidad para la Generación y Síntesis de Evidencias en

15 Salud, Lima, Peru

17 Short title:

18 Lifestyles during COVID-19 in Peru

20 Corresponding author:

21 Carlos J. Toro-Huamanchumo

22 Universidad San Ignacio de Loyola, Vicerrectorado de Investigación, Av. la Fontana 750, La 23 Molina 15024, Lima, Peru

24 Phone: +51944942888

25 E-mail: toro2993@hotmail.com 
27 Eating habits, lifestyle behaviors and stress during the COVID-19 pandemic quarantine

29

30 among Peruvian adults

\section{Abstract}

Background and aims: The coronavirus disease 2019 (COVID-19) outbreak has led to an unprecedented public health crisis. In Peru, although the quarantine is no longer mandatory, it was during the first months of 2020. To date, no studies have assessed the impact of the COVID19 on the eating patterns and lifestyle context in the country. We aimed to describe the eating habits, lifestyle behaviors and stress during the COVID-19 pandemic quarantine among Peruvian adults.

Methods: We conducted a cross-sectional study. We used an online survey to collect information regarding eating habits, self-perceived stress and sedentary lifestyle among adults over 18 years of age residing in Lima-Peru and who complied with strict home quarantine. We presented our data according to the weight variation of the participants.

Results: A total of 686 were finally included in the study. The $82.9 \%$ were female, the median BMI was $25.97 \mathrm{~kg} / \mathrm{m} 2$ (IQR: 23.37-29.41) and 68.2\% reported a significant variation in their weight (38.8\% increased and 29.3 lost weight). All bad habits were significantly associated with weight gain, except for prolonged fasting. Additionally, a sitting time longer than usual $(p=0.001)$, being in front of a screen for more than five hours in the last week $(p=0.002)$, and most of the stressful scenarios were significantly associated with weight gain.

Conclusion: Almost four out of ten participants gained weight during the quarantine. This was associated with unhealthy eating habits, physical inactivity, and stressful scenarios.

Key Words: Life Style; Eating Behavior; COVID-19; Quarantine; Peru 


\section{Introduction}

53 The ongoing coronavirus disease 2019 (COVID-19) outbreak has led to an unprecedented public

54 health crisis and a global health emergency (1). By the end of October 2020, more than 42 million

55 cases and more than 1.1 million deaths had been reported worldwide (2). America is the continent

56 with the highest rate of reported COVID-19 cases, with USA, Brazil and Peru as the most affected

57 countries $(3,4)$.

58

59 Due to the rapid widespread and severe public health disruption, the World Health Organization

60 (WHO) recommended various strategies to reduce the COVID-19 transmission. For example,

61 physical distancing, home quarantine, closure of schools, universities and non-essential

62 businesses, among others (5). Regarding quarantine, although it has had a positive impact on

63 reducing the transmission of COVID-19 $(6,7)$, some studies have reported that it could trigger high

64 levels of anxiety, depressive symptoms and post-traumatic stress disorders (8-10). Naturally, this

65 could also predispose to changes in lifestyles and unhealthy nutritional habits (11-14).

66

67 In Peru, the state of emergency became official on March 16 (15). Since then, physical distancing 68 measures and home quarantine were promoted, and although the quarantine is no longer 69 mandatory (there are only some restriction hours), it was during the first months. To date, few 70 studies have described some lifestyles during the quarantine in Latin America $(16,17)$. However, 71 none of them have been conducted in Peru, which is one of the countries with the highest number 72 of cases and deaths due to COVID-19 worldwide (18).

73

74 This study aimed to describe the eating habits, lifestyle behaviors and stress during the COVID7519 pandemic quarantine among Peruvian adults.

\section{Methods}




\section{Study design}

79 We conducted a cross-sectional study in July, during the mandatory quarantine in Peru.

\section{Study population and context}

82 We included individuals aged 18 years and over who were in Lima at the survey time and with a 83 good precision of the self-reported weight and height ( $\geq 8$ points on a 0-10 scale). For the latter, 84 participants were asked on a scale of 0 (no accuracy) to 10 (total accuracy) to report how accurate 85 they felt when answering the questions regarding their anthropometric values. Surveys with 86 incomplete information were not considered for analysis.

88 Lima is the capital of Peru and is the department with the largest population in the country. According to the National Institute of Statistics and Informatics, by 2018 , it had a total population of 9 million 320000 inhabitants (19).

Variables and instruments

We developed a self-administered web-based 4-section survey. The first section collected sociodemographic data (age, sex, self-reported height and weight and precision of the self-report, marital status and self-report of weight variation from the beginning of the quarantine until the moment of the survey). Weight variation was further categorized in "lost weight" (if the participant lost at least $2.5 \mathrm{~kg}$ ), "weight stable" (no changes or a variation less than $2.5 \mathrm{~kg}$ ) and "gained weight" (if the participant gained at least $2.5 \mathrm{~kg}$ ). The second section consisted of an eating habits questionnaire previously validated in a Spanish-speaking population (20). This questionnaire had 17 items with Likert-type responses ranging from 0 to $6(0=$ never, $1=$ less than once a month, $1012=$ once a month, $3=$ two or three times a month, 4=once or twice per week, 5=three or four times 102 a week, and 6=every day). For the present study, we categorized the responses as: never, one 103 to three times a month, one to four times a week, every day. 
104

105 For the third and fourth sections, we used some questions from the Spanish versions of the "Last

1067 days sedentary behavior questionnaire" (SIT-Q) (21) and the "Perceived Stress Scale" (PSS)

107 (22,23). Both instruments have been used in different studies during the quarantine in the context 108 of COVID-19 (24-26). It is important to mention that, since the present study's objective was 109 mainly descriptive, we opted to only select some questions from each questionnaire.

\section{Procedures}

112 The survey link was distributed using social media (Facebook and other social networking sites)

113 to reach the highest number of participants from all the districts in Lima, Peru. The informed

114 consent was at the beginning of the online (Google $®$ form) survey, including the estimated time

115 needed to complete the survey (15-20 minutes). If a participant wanted to receive his/her detailed

116 results in a personalized way, he/she was asked to enter his/her e-mail. It is important to mention

117 that all participants voluntarily opted for this option. This also allowed us to check and drop 118 duplicates before the analysis.

\section{Statistical analysis}

121 We presented the descriptive results for numeric variables as means with their standard deviation $122(\mathrm{SD})$ or medians with interquartile range (IQR). Categorical variables were presented as 123 frequencies and percentages. According to the weight variation, each of the eating habits, 124 sedentary behaviors, and stressful scenarios items were compared using the one-way ANOVA 125 or the Kruskal Wallis test as appropriate for continuous variables, and the Chi2 or Fisher exact 126 test for categorical variables. We used STATA v16.0 for our analyses. 
129 The Impacta Institutional Review Board, Lima, Peru (RCEI-17) approved the present study. We

130 did not collect personal data, and participation was voluntary and anonymous. The first page of

131 the survey had the consent form. The participants that agreed had to mark the option "I have read

132 the consent form, and I agree with it. I would like to start the survey". Only the participants who

133 marked this option were able to continue with the following survey questions.

\section{Results}

136 A total of 1031 adults completed the survey, and 686 considered that they could report their weight 137 with an accuracy of 8 points or more. The $82.9 \%$ were female, $66 \%$ were single, and the median 138 age was 31 (IQR: 25-41). The median BMI was $25.97 \mathrm{~kg} / \mathrm{m} 2$ (IQR: 23.37-29.41) and 68.2\% reported a significant variation in their weight $(38.8 \%$ increased and 29.3 lost weight) from the start of quarantine to the date of the application of the survey.

142 Table 1-3 reports absolute and relative frequencies of eating habits, sedentary behavior, stressful scenarios and weight variation during the quarantine. Relative frequencies were calculated by rows variables (Questions). Table 1 shows significant differences in most of the eating habits. All bad habits were significantly associated with weight gain, except for prolonged fasting (that was associated with weight loss, $p=0.028$ ). Almost $50 \%$ of the participants who reported gaining weight answered that they had snacks between meals $(p=0.030)$ or had sugar cravings every day $(p=0.001)$. Similarly, these participants were the ones who reported having significantly more snacks between meals $(p=0.002)$. Additionally, a sitting time longer than usual $(p=0.001)$, being in front of a screen for more than five hours in the last week $(p=0.002)$, and most of the stressful scenarios were significantly associated with weight gain (Tables 2 and 3 ). Some of these

152 scenarios included being upset because of something that happened unexpectedly $(p=0.001)$, felt 153 nervous and stressed $(p=0.001)$, found that they could not cope with all the things that they had 
154 to do $(p=0.024)$, and felt difficulties were piling up so high that they could not overcome them $155(p=0.020)$.

156

\section{Discussion}

158 Before describing the eating behaviors during quarantine, it is important to note that it is expected 159 that the availability of food would be restricted during this period. This already makes it difficult to 160 eat healthy foods $(27,28)$. Also, quarantine itself reduces the possibility of physical activity, 161 promoting a sedentary lifestyle (29), which can also generate a significant neuropsychiatric 162 burden (30). This has been evidenced by our results, as the participants manifested different 163 stressful situations during the quarantine. This, in turn, may be related to the excessive intake of "comfort foods" (such as pizzas, fried chicken, burgers, French fries, among others) (31), which naturally leads to weight gain. These foods, mainly rich in sugar and carbohydrates, can reduce stress as they stimulate serotonin production with a positive effect on mood (32). However, this food-craving effect of carbohydrates is proportional to the glycemic index of these "comfort foods", associated with an increased risk of developing obesity and cardiovascular disease, which increase the risk of more severe complications from COVID-19 (33).

171 COVID-19 has had a negative psychological impact worldwide, not only due to the risk of infection

172 but also due to the different measures implemented to contain the outbreak spread $(10,34)$.

173 During the COVID-19 outbreak, several studies have reported an increase in the prevalence of 174 eating disorders (35-37). Similarly, lower psychological health has been associated with higher 175 body shape and weight concerns (38). In this sense, this quarantine can be defined as an 176 unprecedented stressful event that has negatively affected individuals' eating patterns (39). In our 177 study, many participants frequently reported unhealthy eating habits, such as eating until feeling 178 uncomfortable, eating without feeling physical hunger, and feeling guilty or sad after eating. Our 
179 results agree with current evidence that suggests a strong relationship between unhealthy eating 180 behaviors and stress, anxiety and other mental disorders (40).

182 Regular physical activity can be beneficial not only for weight loss but also for strengthening the 183 immune system (41). In fact, low-moderate exercise has proven to be beneficial for the innate 184 immune response against respiratory infections (42) and could improve some clinical conditions 185 related with severe COVID-19 (43). However, this has been limited in some cases due to the 186 closure of gyms and public open spaces. We found a high frequency of sedentary lifestyles and 187 too much time in front of screens during the quarantine. Similar results have been reported in 188 other studies worldwide (44-46). We also found that this sedentary behavior was related to weight 189 gain among the study participants.

190

191 Our study had some limitations. First, the weight variation was self-reported. However, we do not 192 consider this as a continuous variable but rather as an ordinal scale variable. Additionally, 193 participants were asked -on a scale of 1 to 10- to report how accurate they felt they could be 194 answering this question. Only the reliable answers (defined as a score $\geq 8$ ) were chosen. Second, 195 the study was conducted using an online survey. Thus, the population included was the one that 196 responded on social networks or via e-mail. This could limit the extrapolation of our results to the 197 adult population that has access to social media platforms.

Some strengths should also be highlighted. The current study provides valuable information on 200 eating habits and lifestyle behaviors in the context of an unprecedented event worldwide. Moreover, it is the first published study that have addressed this topic in Peru, which is one of the 202 countries with the highest number of cases and deaths due to COVID-19 worldwide. Our results 203 may be useful for implementing public policies to promote healthy lifestyles during the pandemic. 
204 In addition, our study provides insight for future research to implement and evaluate different 205 coping strategies to avoid comorbidities associated with weight gain, especially for future 206 circumstances that will again require self-quarantine.

207

208 In conclusion, almost 4 out of 10 participants reported an increase of $3-5 \mathrm{~kg}$ in their weight. This 209 was related to some unhealthy eating behaviors and a sedentary lifestyle. The awareness of these 210 factors could be an opportunity to promote nutrition and physical activity programs across the 211 country, especially since most of them are potentially modifiable. Additionally, we recommend 212 implementing community-based strategies to promote coping skills and support resilience during 213 the COVID-19 pandemic.

214

215 Acknowledgments

216 To Marilyn Espantoso and Erick Piskulich for their support in data collection.

217

218 Conflict of interests

219 None to declare.

220

221 Funding

222 This study was self-funded.

223

224 References 
225 1. Arshad Ali S, Baloch M, Ahmed N, Arshad Ali A, lqbal A. The outbreak of Coronavirus 226 Disease 2019 (COVID-19)-An emerging global health threat. J Infect Public Health. $227 \quad 2020 ; 13(4): 644-6$.

228 2. World Health Organization. COVID-19 Weekly Epidemiological Update [Internet]. Geneva: 229 WHO; 2020. Available online: https://www.who.int/publications/m/item/weekly-epidemiological230 update---27-october-2020

231 3. Acosta LD. Capacidad de respuesta frente a la pandemia de COVID-19 en América Latina 232 y el Caribe. Rev Panam Salud Pública. 2020;44:e109.

233 4. Rodriguez-Morales AJ, Gallego V, Escalera-Antezana JP, Méndez CA, Zambrano LI, 234 Franco-Paredes C, et al. COVID-19 in Latin America: The implications of the first confirmed case 235 in Brazil. Travel Med Infect Dis. 2020;35:101613.

236 5. World Health Organization. Public health considerations while resuming international 237 travel [Internet]. Geneva: WHO; 2020. Available online: https://www.who.int/news-room/articles238 detail/public-health-considerations-while-resuming-international-travel

239 6. Sen S, Karaca-Mandic P, Georgiou A. Association of Stay-at-Home Orders With COVID24019 Hospitalizations in 4 States. JAMA. 2020;323(24):2522-4.

241 7. Pan A, Liu L, Wang C, Guo H, Hao X, Wang Q, et al. Association of Public Health 242 Interventions With the Epidemiology of the COVID-19 Outbreak in Wuhan, China. JAMA. $2432020 ; 323(19): 1-9$.

244 8. Brooks SK, Webster RK, Smith LE, Woodland L, Wessely S, Greenberg N, et al. The 245 psychological impact of quarantine and how to reduce it: rapid review of the evidence. Lancet. 246 2020;395(10227):912-20.

247 9. Fawaz M, Samaha A. COVID-19 quarantine: Post-traumatic stress symptomatology 248 among Lebanese citizens. Int J Soc Psychiatry. 2020;66(7): 666-74. 
250 10. Guo Y, Cheng C, Zeng Y, et al. Mental Health Disorders and Associated Risk Factors in 251 Quarantined Adults During the COVID-19 Outbreak in China: Cross-Sectional Study. J Med 252 Internet Res. 2020;22(8):e20328

253 11. Papandreou C, Arija V, Aretouli E, et al. Comparing eating behaviours, and symptoms of 254 depression and anxiety between Spain and Greece during the COVID-19 outbreak: 255 Cross-sectional analysis of two different confinement strategies. Eur Eat Disord Rev. $256 \quad 2020: 10.1002 / e r v .2772$.

257 12. Di Renzo L, Gualtieri P, Pivari F, et al. Eating habits and lifestyle changes during COVID25819 lockdown: an Italian survey. J Transl Med. 2020;18:229.

259 13. Górnicka M, Drywień ME, Zielinska MA, et al. Dietary and Lifestyle Changes During COVID26019 and the Subsequent Lockdowns among Polish Adults: A Cross-Sectional Online Survey 261 PLifeCOVID-19 Study. Nutrients. 2020;12(8):2324.

262 14. Ruiz-Roso MB, Knott-Torcal C, Matilla-Escalante DC, Garcimartín A, Sampedro-Nuñez 263 MA, Dávalos A, et al. COVID-19 Lockdown and Changes of the Dietary Pattern and Physical 264 Activity Habits in a Cohort of Patients with Type 2 Diabetes Mellitus. Nutrients. 2020;12(8):2327.

265 15. Presidencia del Consejo de Ministros. Decreto Supremo Nº44-2020-PCM. Peru: PCM; 266 2010. Available from: https://www.gob.pe/institucion/pcm/normas-legales/460472-044-2020-pcm

267 16. Werneck AO, Silva DR, Malta DC, et al. Changes in the clustering of unhealthy movement 268 behaviors during the COVID-19 quarantine and the association with mental health indicators 269 among Brazilian adults. Transl Behav Med. 2020;ibaa095

270 17. Ruíz-Roso MB, de Carvalho Padilha P, Matilla-Escalante DC, et al. Changes of Physical 271 Activity and Ultra-Processed Food Consumption in Adolescents from Different Countries during 272 Covid-19 Pandemic: An Observational Study. Nutrients. 2020;12(8):2289 
273 18. World Health Organization. WHO Health Emergency Dashboard [Internet]. Geneva: 274 WHO; 2021. Available from: https://covid19.who.int

275 19. Instituto Nacional de Estadística e Informática. Nota de Prensa Nº 007 - 18 Enero 2018: 276 Lima alberga 9 millones 320 mil habitantes al 2018 [Internet]. Lima, Peru: INEI; 2018. Available 277 from: https://www.inei.gob.pe/media/MenuRecursivo/noticias/nota-de-prensa-n-007-2018-inei278 2.pdf

279 20. Reséndiz Barragán AM, Hernández Altamirano SV, Sierra Murguía MA, Torres Tamayo 280 M. Hábitos de alimentación de pacientes con obesidad severa. Nutr Hosp. 2015;31(2):672-81.

281 21. Felez-Nobrega M, Bort-Roig J, Dowd KP, Wijndaele K, Puig-Ribera A. Validation study of 282 the Spanish version of the Last-7-d Sedentary Time Questionnaire (SIT-Q-7d-Sp) in young adults. 283 PLoS ONE. 2019;14(5):e0217362.

284 22. Baik SH, Fox RS, Mills SD, Roesch SC, Sadler GR, Klonoff EA, et al. Reliability and 285 validity of the Perceived Stress Scale-10 in Hispanic Americans with English or Spanish language 286 preference. J Health Psychol. 2019;24(5):628-39.

287 23. Remor E. Psychometric Properties of a European Spanish Version of the Perceived Stress 288 Scale (PSS). Span J Psychol. 2006;9(1):86-93.

289 24. Zachary Z, Brianna F, Brianna L, Garrett P, Jade W, Alyssa D, et al. Self-quarantine and 290 weight gain related risk factors during the COVID-19 pandemic. Obes Res Clin Pract. $2912020 ; 14(3): 210-6$.

292 25. Gallè F, Sabella EA, Ferracuti S, De Giglio O, Caggiano G, Protano C, et al. Sedentary 293 Behaviors and Physical Activity of Italian Undergraduate Students during Lockdown at the Time 294 of CoViD-19 Pandemic. Int J Environ Res Public Health. 2020;17(17):6171. 
295 26. lasevoli F, Fornaro M, D’Urso G, Galletta D, Casella C, Paternoster M, et al. Psychological 296 distress in patients with serious mental illness during the COVID-19 outbreak and one-month 297 mass quarantine in Italy. Psychol Med. 2020;1-3.

298 27. Díez J, Bilal U, Franco M. Unique features of the Mediterranean food environment: 299 Implications for the prevention of chronic diseases Rh: Mediterranean food environments. Eur J 300 Clin Nutr. 2019;72(1):71-5.

301 28. Bilal U, Jones-Smith J, Diez J, Lawrence RS, Celentano DD, Franco M. Neighborhood 302 social and economic change and retail food environment change in Madrid (Spain): The heart 303 healthy hoods study. Health Place. 2018;51:107-17.

304 29. Fernández-Sanjurjo M, de Gonzalo-Calvo D, Fernández-García B, Díez-Robles S, 305 Martínez-Canal Á, Olmedillas H, et al. Circulating microRNA as Emerging Biomarkers of Exercise: 306 Exerc Sport Sci Rev. 2018;46(3):160-71.

307 30. Troyer EA, Kohn JN, Hong S. Are we facing a crashing wave of neuropsychiatric sequelae 308 of COVID-19? Neuropsychiatric symptoms and potential immunologic mechanisms. Brain Behav 309 Immun. 2020;87:34-9.

310 31. Moynihan AB, Tilburg WAP van, Igou ER, et al. Eaten up by boredom: consuming food to 311 escape awareness of the bored self. Front Psychol. 2015;6:369.

312 32. Lima CKT, Carvalho PM de M, Lima I de AAS, Nunes JVA de O, Saraiva JS, de Souza

313 RI, et al. The emotional impact of Coronavirus 2019-nCoV (new Coronavirus disease). Psychiatry 314 Res. 2020;287:112915.

315 33. Yannakoulia M, Panagiotakos DB, Pitsavos C, Tsetsekou E, Fappa E, Papageorgiou C, 316 et al. Eating habits in relations to anxiety symptoms among apparently healthy adults: A pattern 317 analysis from the ATTICA study. Appetite. 2008;51(3):519-25. 
318 34. Lal A, Sanaullah A, M. Saleem MK, Ahmed N, Maqsood A, Ahmed N. Psychological 319 Distress among Adults in Home Confinement in the Midst of COVID-19 Outbreak. Eur J Dent. $3202020 ; \mathrm{s}-0040-1718644$.

321 35. Cooper M, Reilly EE, Siegel JA, Coniglio K, Sadeh-Sharvit S, Pisetsky EM, et al. Eating 322 disorders during the COVID-19 pandemic and quarantine: an overview of risks and 323 recommendations for treatment and early intervention. Eat Disord. 2020;1-23.

324 36. Baenas I, Caravaca-Sanz E, Granero R, Sánchez I, Riesco N, Testa G, et al. COVID-19 325 and eating disorders during confinement: Analysis of factors associated with resilience and 326 aggravation of symptoms. Eur Eat Disord Rev. 2020:10.1002/erv.2771.

327 37. Phillipou A, Meyer D, Neill E, Tan EJ, Toh WL, Van Rheenen TE, et al. Eating and exercise 328 behaviors in eating disorders and the general population during the COVID-19 pandemic in 329 Australia: Initial results from the COLLATE project. Int J Eat Disord. 2020:10.1002/eat.23317.

330 38. Haddad C, Zakhour M, Bou kheir M, Haddad R, Al Hachach M, Sacre H, et al. Association 331 between eating behavior and quarantine/confinement stressors during the coronavirus disease 3322019 outbreak. J Eat Disord. 2020;8:40.

333 39. Bin Zarah A, Enriquez-Marulanda J, Andrade JM. Relationship between Dietary Habits, 334 Food Attitudes and Food Security Status among Adults Living within the United States Three 335 Months Post-Mandated Quarantine: A Cross-Sectional Study. Nutrients. 2020 12(11):3468.

336 40. Yau YHC, Potenza MN. Stress and Eating Behaviors. Minerva Endocrinol. 337 2013;38(3):255-67.

338 41. Zheng Q, Cui G, Chen J, Gao H, Wei Y, Uede T, et al. Regular Exercise Enhances the 339 Immune Response Against Microbial Antigens Through Up-Regulation of Toll-like Receptor 340 Signaling Pathways. Cell Physiol Biochem. 2015;37(2):735-46. 
341 42. Matricardi PM, Dal Negro RW, Nisini R. The first, holistic immunological model of

342 COVID-19: implications for prevention, diagnosis, and public health measures. Pediatr Allergy

343 Immunol. 2020:10.1111/pai.13271.

344 43. Dwyer MJ, Pasini M, De Dominicis S, Righi E. Physical activity: Benefits and challenges 345 during the COVID-19 pandemic. Scand J Med Sci Sports. 2020;30(7):1291-4.

346 44. Meyer J, McDowell C, Lansing J, et al. Changes in Physical Activity and Sedentary 347 Behavior in Response to COVID-19 and Their Associations with Mental Health in 3052 US Adults. 348 Int J Environ Res Public Health. 2020;17(18):6469.

349 45. Zheng C, Huang WY, Sheridan S, et al. COVID-19 Pandemic Brings a Sedentary Lifestyle 350 in Young Adults: A Cross-Sectional and Longitudinal Study. Int J Environ Res Public Health. $3512020 ; 17(17): 6035$.

352 46. Ruiz-Roso MB, de Carvalho Padilha P, Mantilla-Escalante DC, Ulloa N, Brun P, Acevedo353 Correa D, et al. Covid-19 Confinement and Changes of Adolescent's Dietary Trends in Italy, 354 Spain, Chile, Colombia and Brazil. Nutrients. 2020;12(6):1807. 


\section{Table $\mathbf{1}$ (on next page)}

Table 1. Eating habits and weight variation during quarantine 
1 Table 1. Eating habits and weight variation during quarantine

\begin{tabular}{|c|c|c|c|c|}
\hline Question & $\begin{array}{l}\text { Lost weight } \\
(\mathrm{n}=201)\end{array}$ & $\begin{array}{l}\text { Weight stable } \\
(\mathrm{n}=218)\end{array}$ & $\begin{array}{l}\text { Gained weight } \\
(\mathrm{n}=267)\end{array}$ & $\mathrm{p}$ \\
\hline \multicolumn{5}{|l|}{ "How often do you..." } \\
\hline Snack between meals? & & & & $0.030^{*}$ \\
\hline Never & $24(42.9)$ & $15(26.8)$ & $17(30.4)$ & \\
\hline One to three times a month & $32(33.3)$ & $35(36.5)$ & $29(30.2)$ & \\
\hline One to four times a week & $85(27.6)$ & $106(34.4)$ & $117(38.0)$ & \\
\hline Everyday & $60(26.6)$ & $62(27.4)$ & $104(46.0)$ & \\
\hline Have long fasting periods? & & & & $0.028^{*}$ \\
\hline Never & $99(27.1)$ & $106(29.0)$ & $160(43.8)$ & \\
\hline One to three times a month & $43(29.3)$ & $56(38.1)$ & $48(32.7)$ & \\
\hline One to four times a week & $40(29.9)$ & $45(33.6)$ & $49(36.6)$ & \\
\hline Everyday & $19(47.5)$ & $11(27.5)$ & $10(25.0)$ & \\
\hline Eat until you feel uncomfortable? & & & & $0.001^{*}$ \\
\hline Never & $79(30.7)$ & $98(38.1)$ & $80(31.1)$ & \\
\hline One to three times a month & $90(31.4)$ & $97(33.8)$ & $100(34.8)$ & \\
\hline One to four times a week & $28(23.7)$ & $19(16.1)$ & $71(60.2)$ & \\
\hline Everyday & $4(16.7)$ & $4(16.7)$ & $16(66.7)$ & \\
\hline $\begin{array}{l}\text { Eat without feeling physical } \\
\text { hunger? }\end{array}$ & & & & $0.001^{*}$ \\
\hline Never & $56(30.0)$ & $77(41.2)$ & $54(28.9)$ & \\
\hline One to three times a month & $81(31.9)$ & $89(35.0)$ & $84(33.1)$ & \\
\hline One to four times a week & $55(29.7)$ & $41(22.2)$ & $89(48.1)$ & \\
\hline Everyday & $9(15.0)$ & $11(18.3)$ & $40(66.7)$ & \\
\hline Feel guilty or sad after eating? & & & & $0.001^{*}$ \\
\hline Never & $72(31.4)$ & $103(45.0)$ & $54(23.6)$ & \\
\hline One to three times a month & $83(34.3)$ & $78(32.2)$ & $81(33.5)$ & \\
\hline One to four times a week & $32(26.2)$ & $23(18.8)$ & $67(54.9)$ & \\
\hline Everyday & $14(15.1)$ & $14(15.1)$ & $85(34.3)$ & \\
\hline Stressed by the way you eat? & & & & $0.001^{*}$ \\
\hline Never & $85(34.3)$ & $111(44.8)$ & $52(21.0)$ & \\
\hline One to three times a month & $54(27.6)$ & $71(36.2)$ & $71(36.2)$ & \\
\hline One to four times a week & $43(34.1)$ & $20(15.9)$ & $63(50.0)$ & \\
\hline Everyday & $19(16.4)$ & $16(13.8)$ & $81(69.8)$ & \\
\hline $\begin{array}{l}\text { Drink sodas, processed juices or } \\
\text { shakes? }\end{array}$ & & & & $0.001^{*}$ \\
\hline Never & $47(32.2)$ & $57(39.0)$ & $42(28.8)$ & \\
\hline One to three times a month & $119(32.0)$ & $115(30.9)$ & $138(37.1)$ & \\
\hline One to four times a week & $31(20.7)$ & $39(26.0)$ & $80(53.3)$ & \\
\hline Everyday & $4(22.2)$ & $7(38.9)$ & $7(38.9)$ & \\
\hline Drink water? & & & & $0.001^{*}$ \\
\hline Never & $3(15.8)$ & $3(15.8)$ & $13(68.4)$ & \\
\hline One to three times a month & $9(34.6)$ & $3(11.5)$ & $14(53.9)$ & \\
\hline One to four times a week & $26(21.9)$ & $33(27.7)$ & $60(50.4)$ & \\
\hline Everyday & $163(31.2)$ & $179(34.3)$ & $180(34.5)$ & \\
\hline Have sugar cravings? & & & & $0.001^{*}$ \\
\hline Never & $11(36.7)$ & $11(36.7)$ & $8(26.7)$ & \\
\hline One to three times a month & $75(36.6)$ & $70(34.2)$ & $60(29.3)$ & \\
\hline One to four times a week & $74(28.7)$ & $90(34.9)$ & $94(36.4)$ & \\
\hline
\end{tabular}




\begin{tabular}{|c|c|c|c|c|}
\hline Everyday & $41(21.24)$ & $47(24.4)$ & $105(54.4)$ & \\
\hline Have salt cravings? & & & & $0.001^{*}$ \\
\hline Never & $20(31.8)$ & $26(41.3)$ & $17(27.0)$ & \\
\hline One to three times a month & $86(34.4)$ & $88(35.2)$ & $76(30.4)$ & \\
\hline One to four times a week & $65(24.9)$ & $75(28.7)$ & $121(46.4)$ & \\
\hline Everyday & $30(26.8)$ & $29(25.9)$ & $53(47.3)$ & \\
\hline Have cravings for fatty foods? & & & & $0.001^{*}$ \\
\hline Never & $21(25.92)$ & $39(48.2)$ & $21(25.9)$ & \\
\hline One to three times a month & $123(33.8)$ & $125(34.3)$ & $116(31.9)$ & \\
\hline One to four times a week & $47(24.1)$ & $44(22.6)$ & $104(53.3)$ & \\
\hline Everyday & $10(21.7)$ & $10(21.7)$ & $26(56.5)$ & \\
\hline Drink natural juices? & & & & $0.007^{*}$ \\
\hline Never & $30(43.5)$ & $16(23.2)$ & $23(33.3)$ & \\
\hline One to three times a month & $72(28.8)$ & $82(32.8)$ & $96(38.4)$ & \\
\hline One to four times a week & $71(29.3)$ & $66(27.3)$ & $105(43.4)$ & \\
\hline Everyday & $28(22.4)$ & $54(43.2)$ & $43(34.4)$ & \\
\hline $\begin{array}{l}\text { Leave the plate "empty" when } \\
\text { you finish eating? }\end{array}$ & & & & $0.538^{*}$ \\
\hline Never & $10(38.5)$ & $10(38.5)$ & $6(23.1)$ & \\
\hline One to three times a month & $9(25.0)$ & $10(27.8)$ & $17(47.2)$ & \\
\hline One to four times a week & $41(29.1)$ & $40(28.4)$ & $60(42.6)$ & \\
\hline Everyday & $141(29.2)$ & $158(32.7)$ & $184(38.1)$ & \\
\hline Have breakfast in the week? & & & & $0.016^{*}$ \\
\hline One to two days & $24(39.3)$ & $18(29.5)$ & $19(31.2)$ & \\
\hline Three to five days & $32(25.4)$ & $30(23.8)$ & $64(50.8)$ & \\
\hline Six to seven days & $145(29.1)$ & $170(34.1)$ & $184(36.9)$ & \\
\hline Have lunch in the week? & & & & $0.756^{*}$ \\
\hline One to two days & $5(25.0)$ & $6(30.0)$ & $9(45.0)$ & \\
\hline Three to five days & $10(23.8)$ & $12(28.6)$ & $20(47.6)$ & \\
\hline Six to seven days & $186(29.8)$ & $200(32.1)$ & $238(38.1)$ & \\
\hline Have dinner in the week? & & & & $0.016^{*}$ \\
\hline One to two days & $29(40.9)$ & $19(26.8)$ & $23(32.4)$ & \\
\hline Three to five days & $37(21.8)$ & $52(30.6)$ & $81(47.7)$ & \\
\hline Six to seven days & $135(30.3)$ & $147(33.0)$ & $163(36.6)$ & \\
\hline "How many..." & & & & \\
\hline $\begin{array}{l}\text { Main meals do you have per } \\
\text { day? }\end{array}$ & $3(2-3)$ & $3(2-3)$ & $3(2-3)$ & $0.198^{\dagger}$ \\
\hline $\begin{array}{l}\text { Snacks between meals do you } \\
\text { have per day? } \\
\text { Do you... }\end{array}$ & $1.30(0.88)$ & $1.25(0.79)$ & $1.51(0.82)$ & $0.002^{\dagger \dagger}$ \\
\hline $\begin{array}{l}\text { Skip meals to take care of your } \\
\text { figure? }\end{array}$ & & & & $0.001^{*}$ \\
\hline No & $53(21.0)$ & $88(34.8)$ & $112(44.3)$ & \\
\hline Yes & $148(34.2)$ & $130(30.02)$ & $155(35.8)$ & \\
\hline \multicolumn{5}{|l|}{${ }^{*}$ Chi2 test } \\
\hline tKruskal Wallis & & & & \\
\hline ††ANOVA & & & & \\
\hline
\end{tabular}


Table 2 (on next page)

Table 2. Sedentary behavior and weight variation during quarantine 
1 Table 2. Sedentary behavior and weight variation during quarantine

2

\begin{tabular}{|c|c|c|c|c|}
\hline $\begin{array}{l}\text { Question: "In the last week, how } \\
\text { long..." }\end{array}$ & $\begin{array}{l}\text { Lost weight } \\
\qquad(\mathrm{n}=201)\end{array}$ & $\begin{array}{l}\text { Weight stable } \\
\quad(n=218)\end{array}$ & $\begin{array}{l}\text { Gained weight } \\
\quad(n=267)\end{array}$ & $p$ \\
\hline $\begin{array}{l}\text { Have you been sitting or lying } \\
\text { down? }\end{array}$ & & & & $0.001^{*}$ \\
\hline Less than normal & $36(43.9)$ & $25(30.5)$ & $21(25.6)$ & \\
\hline About the same & $45(35.7)$ & $50(39.7)$ & $31(24.6)$ & \\
\hline More than usual & $120(25.1)$ & $143(29.9)$ & $215(45.0)$ & \\
\hline $\begin{array}{l}\text { Did you sit for breakfast, lunch, } \\
\text { or dinner? }\end{array}$ & & & & $0.940^{*}$ \\
\hline$<30 \min$ & $129(29.5)$ & $142(32.5)$ & $166(38.0)$ & \\
\hline $30-60$ min & $51(30.0)$ & $51(30.0)$ & $68(40.0)$ & \\
\hline$>1$ hour & $21(26.6)$ & $25(31.7)$ & $33(41.8)$ & \\
\hline $\begin{array}{l}\text { Did you sit or lie down in front of } \\
\text { a screen? }\end{array}$ & & & & $0.002^{*}$ \\
\hline$<60 \min$ & $51(33.1)$ & $54(35.1)$ & $49(31.8)$ & \\
\hline $1-3$ hours & $60(35.1)$ & $55(32.2)$ & $56(32.8)$ & \\
\hline $3-5$ hours & $30(29.4)$ & $38(37.3)$ & $34(33.3)$ & \\
\hline$>5$ hours & $60(23.2)$ & $71(27.4)$ & $128(49.4)$ & \\
\hline Did you sit while reading a book? & & & & $0.469^{*}$ \\
\hline$<60 \min$ & $171(29.7)$ & $183(31.8)$ & $221(38.4)$ & \\
\hline $1-3$ hours & $26(28.9)$ & $25(27.8)$ & $39(43.3)$ & \\
\hline $3-5$ hours & $4(19.1)$ & $10(47.6)$ & 7 (33.3) & \\
\hline $\begin{array}{l}\text { Did you sit while playing cards or } \\
\text { solving puzzles? }\end{array}$ & & & & $0.244 \dagger$ \\
\hline$<60 \min$ & $177(29.1)$ & $187(30.8)$ & $244(40.1)$ & \\
\hline $1-3$ hours & $18(28.6)$ & $27(42.9)$ & $18(28.6)$ & \\
\hline $3-5$ hours & $6(40.0)$ & $4(26.7)$ & 5 (33.3) & \\
\hline $\begin{array}{l}\text { Did you sit while listening to } \\
\text { music? }\end{array}$ & & & & $0.333^{*}$ \\
\hline$<60 \min$ & $134(28.4)$ & $157(33.3)$ & $181(38.4)$ & \\
\hline 1 - 3 hours & $47(34.8)$ & $39(28.9)$ & $49(36.3)$ & \\
\hline $3-5$ hours & $20(25.3)$ & $22(27.9)$ & $37(46.8)$ & \\
\hline
\end{tabular}

${ }^{*}$ Chi2 test

†Fisher exact test 


\section{Table 3 (on next page)}

Table 3. Stressful scenarios and weight variation during quarantine 
1 Table 3. Stressful scenarios and weight variation during quarantine

\begin{tabular}{|c|c|c|c|c|}
\hline $\begin{array}{l}\text { Question: } \\
\text { "In the last month, how often have } \\
\text { you..." }\end{array}$ & $\begin{array}{l}\text { Lost weight } \\
(n=201)\end{array}$ & $\begin{array}{l}\text { Weight stable } \\
(\mathrm{n}=218)\end{array}$ & $\begin{array}{l}\text { Gained } \\
\text { weight } \\
(n=267)\end{array}$ & $\mathrm{p}$ \\
\hline $\begin{array}{l}\text { Been upset because of something that } \\
\text { happened unexpectedly }\end{array}$ & & & & $0.001^{*}$ \\
\hline Never or almost never & $57(32.8)$ & $64(36.8)$ & $53(30.5)$ & \\
\hline Sometimes & $90(28.0)$ & $113(35.1)$ & $119(37.0)$ & \\
\hline Fairly often or very often & $54(28.4)$ & $41(21.6)$ & $95(50.0)$ & \\
\hline $\begin{array}{l}\text { You felt that you were unable to control } \\
\text { the important things in your life? }\end{array}$ & & & & $0.051^{*}$ \\
\hline Never or almost never & $83(31.9)$ & $89(34.2)$ & $88(33.9)$ & \\
\hline Sometimes & $78(29.1)$ & $88(32.8)$ & $102(38.1)$ & \\
\hline Fairly often or very often & $40(25.3)$ & $41(26.0)$ & $77(48.7)$ & \\
\hline Felt nervous and "stressed"? & & & & $0.001^{*}$ \\
\hline Never or almost never & $39(37.5)$ & $32(30.8)$ & $33(31.7)$ & \\
\hline Sometimes & $74(28.2)$ & $102(38.9)$ & $86(32.8)$ & \\
\hline Fairly often or very often & $88(27.5)$ & $84(26.3)$ & $148(46.3)$ & \\
\hline $\begin{array}{l}\text { Felt confident about your ability to } \\
\text { handle your personal problems? }\end{array}$ & & & & $0.263^{*}$ \\
\hline Never or almost never & $14(26.4)$ & 19 (35.9) & $20(37.7)$ & \\
\hline Sometimes & $51(25.1)$ & $61(30.1)$ & $91(44.8)$ & \\
\hline Fairly often or very often & $136(31.6)$ & $138(32.1)$ & $156(36.3)$ & \\
\hline Felt that things were going your way? & & & & $0.001^{*}$ \\
\hline Never or almost never & 13(33.3) & $9(23.1)$ & $17(43.6)$ & \\
\hline Sometimes & $49(20.6)$ & $75(31.5)$ & $114(47.9)$ & \\
\hline Fairly often or very often & $139(34.0)$ & $134(32.8)$ & $136(33.3)$ & \\
\hline $\begin{array}{l}\text { Found that you could not cope with all } \\
\text { the things that you had to do? }\end{array}$ & & & & $0.024^{*}$ \\
\hline Never or almost never & $87(34.1)$ & $81(31.8)$ & $87(34.1)$ & \\
\hline Sometimes & $85(27.8)$ & $104(34.0)$ & $117(38.2)$ & \\
\hline Fairly often or very often & $29(23.2)$ & $33(26.4)$ & $63(50.4)$ & \\
\hline $\begin{array}{l}\text { Been able to control irritations in your } \\
\text { life? }\end{array}$ & & & & $0.034^{*}$ \\
\hline Never or almost never & $3(14.3)$ & $9(42.9)$ & $9(42.9)$ & \\
\hline Sometimes & $44(26.7)$ & $42(25.5)$ & $79(47.9)$ & \\
\hline Fairly often or very often & $154(30.8)$ & $167(33.4)$ & $179(35.8)$ & \\
\hline Felt that you were on top of things? & & & & $0.056^{*}$ \\
\hline Never or almost never & $13(21.5)$ & $24(36.9)$ & $27(41.5)$ & \\
\hline Sometimes & $60(24.8)$ & $75(31.0)$ & $107(44.2)$ & \\
\hline Fairly often or very often & $127(33.5)$ & $119(31.4)$ & $133(35.1)$ & \\
\hline $\begin{array}{l}\text { Felt difficulties were piling up so high } \\
\text { that you could not overcome them? }\end{array}$ & & & & $0.020^{*}$ \\
\hline Never or almost never & $108(32.2)$ & $115(34.3)$ & $112(33.4)$ & \\
\hline Sometimes & $69(27.4)$ & $79(31.4)$ & $104(41.3)$ & \\
\hline Fairly often or very often & $24(24.2)$ & $24(24.2)$ & $51(51.5)$ & \\
\hline
\end{tabular}

${ }^{*}$ Chi2 test 